\title{
URGENSI KEKUATAN POLITIK DALAM PENAFSIRAN Al-QUR'AN
}

\author{
Oleh : Darlis. Lc. M.S.I
}

\begin{abstract}
Interpretation is a science used to interpret. Every exegete will certainly be affected in a neighborhood where he lives. Therefore politics is also one of the factors that influence the interpreter. An example is the exegete Rashid Ridho and his teacher who formed interpretations with the aim of eliminating superstition and superstition. This work will showcase some of the works of commentators affected by the environment. By using library research the author will track some interpretations that are affected by the environment. After finding the interpretation of the verse, then the writer will trace the reasons for the influence of the interpreters in their respective environments. In this paper also comes with original sources from the interpreters to be tracked.
\end{abstract}




\begin{abstract}
Abstrak
Tafsir merupakan sebuah ilmu yang digunakan untuk menginterpretasikan. Setiap mufasir pasti akan terpengaruh dalam sebuah ilngkungan tempat tinggal dia berasal. Oleh karena itu politik juga salah satu faktor yang mempengaruhi si penafsir. Contohnya adalah mufasir Rasyid Ridho dan gurunya yang membentuk tafsir dengan tujuan menghilangkan khurafat dan tahayul. Karya ini akan memperlihatkan beberapa karya mufasir yang terpengaruh oleh lingkungan. Dengan menggunakan library research penulis akan melacak beberapa penafsiran yang terpengaruh oleh lingkungan. Setelah ditemukan tafsiran ayat, kemudian penulis akan melacak alasan terpengaruhnya para mufasir di lingkungan mereka masing-masing. Dalam tulisan ini juga dilengkapi dengan sumber-sumber original dari mufasir yang akan dilacak.

Kata Kunci: Tafsir, Politik dan Mufasir
\end{abstract}




\section{Pendahuluan}

Tafsir secara bahasa (الإيضاح و التبين) artinya penjelasan, Sedangkan secara istilah sebagian ulama mendefenisikan tafsir bukanlah bagian dari yang ilmu-ilmu yang tidak ada ikatan (pemaksaan padanya). Karena sesungguhnya tafsir itu bukanlah kaidah-kaidah dalam sebuah ilmu yang dimlikinya, akan tetapi hal itu menyerupai ilmu akal dan membutuhkan penjelasan dari kalam Allah atau suatu penjelasan terhadap lafadz al-Qur'an. ${ }^{1}$

Terlihat jelas bahwasanya tafsir itu dibangun atas dasar pemikiran oleh sipembaca, secara jelas ini terkait dengan konteks lingkungan yang ada disekitarnya, sejauh mana penafsir itu melibatkan dirinya dalam lingkungan, bahkan bisa saja seorang mufasir itu secara tidak sengaja terpengaruh dalam karyanya. Sebagai contoh karya Muhammad Rasyid Ridha dengan Ustadz nya bernama Muhammad Abduh dalam tafsir al-Manar yang ingin menghilangkan khurafat dan mitos dalam negerinya.

Penulis mengambil istilah Nasr Hamid Abu Zaid yang mengatakan bahwa peradaban Islam dibangun atas dasar peradaban teks, hal ini terlihat dari sejarah bangsa arab yang sangat kental dengan syair-syair. Bahkan Imam Syafi'i menjadikan teks sebagai rujukan utama dalam membahas persolan-persoalam Umat Islam baik itu bersifat ritual ataupun sosial. ${ }^{2}$

${ }^{1}$ Muhammad Husein al-Dzahabī, al-Tafsīr wal al-Mufassinūn (Beirut : Maktabah Mus’ab bin Umar, 2004), h. 12.

2 M Hilaly Basya, "Mendialogkan Teks Agama dengan Makna Zaman Menuju Transformasi Sosial” al-Huda Vol III (2005), h. 10-9. 
Pada hakikatnya benar tentang pendapat Nasr hal ini bisa kita lihat bahwasanya al-Qur'an dijadikan teks yang suci bahkan sakral, bahkan pengumpulannya menjadi problem umat pada saat itu, khususnya pada masa Abu Bakar al-Shidiq r.a. Pada saat itu Umar r.a merasa khawatir tentang kematian para hufadz yang terjadi akibat perang Yamamah. ${ }^{3}$

Bahkan hal ini pun berlanjut pada masa Ustman bin Affan yang mendengar cerita dari Hudzaifah al-Yaman yang melihat banyak perbedaan mengenai cara membaca al-Qur'an, dan hal ini langsungdi respon oleh Ustman yang pada saat itu menjadi khalifah dan menyuruh Zaid bin Tsabit, Abdullah bin Zubair, Said bin As dan Abdurahman bin Haris bin Hisyam agar menyalin al-Qur'an dalam satu bacaan. Sebagaimana riwayat dalam Sohih Bulhari : ${ }^{4}$

$$
\begin{aligned}
& \text { حدثنا موسى بن إسماعيل عن إبراهيم بن سعد حدثنا ابن شهاب عن عبيد بن السباق أن زيد بن ثابت ئدئ. }
\end{aligned}
$$

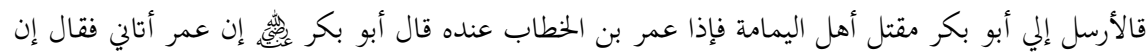

$$
\begin{aligned}
& \text { القتل قد استحر يوم اليمامة بقراء القرآن وإني أخشى أن يستحر القتل بالقراء بلمواطن فيذهب كثير من }
\end{aligned}
$$

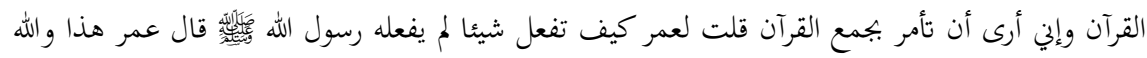

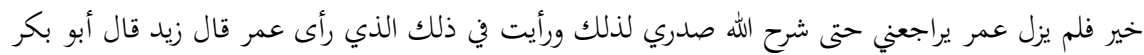

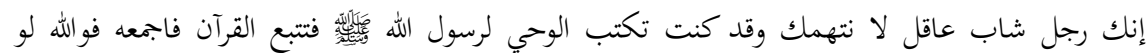

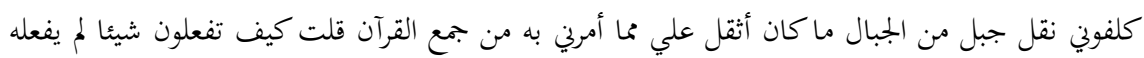

$$
\begin{aligned}
& \text { رسول الله }
\end{aligned}
$$

${ }^{3}$ Mannā' Khalīl al-Qaț̣ān, Studi IImu-Ilmu al-Qur’an, (Bogor : Pustaka Litera Antar Nusa, 2004), h. 189-188.

${ }^{4}$ Abdullah bin Muhammad bin Ismail bin Ibrahim bin Mughirah bin Bardizbah al-Buhori, Sohih al-Bukhori (Kairo : Dār al-Hadìts, 2004), h. 324. 


$$
\text { التوبة مع أبي خزيمة الأنصاري لم أجدما فتتبعت القرآن أجمعه من العسب واللخاف وصدور الرجال حتى وجدت آخر سورة }
$$

Peristiwa yang disampaikan penulis diatas sangat jelas bahwa peristiwa pengumpulan al-Qur'an sangat kental terhadap politik. Hemat penulis ketika melihat history dari al-Quran yang sangat kental unsur politiknya, hal ini menambahkan keyakinan penulis bahwa sejarah pengumpulan al-Quran pun sudah ada unsur politiknya apalagi penafsirannya yang kental dengan subjektifitas penafsir dan lingkungan sekitarnya.

Jika sekiranya pengumpulan al-Qur'an itu tidak terdapat unsur politiknya mustahil Umar bin Khatab melapor kepada Abu Bakar as-Shidīq yang pada saat itu sebagai khalifah, secara tidak langsung hal ini mengindikasikan bahwa kepemimpinan dalam suatu politik khususnya di tanah Arab sangat berpengaruh. Jika Umar bin Khatab melakukannya secara pribadi bisa saja al-Qur'an sebagai kitab Umat Islam tidak akan sampai di zaman sekarang.

Peristiwa berikutnya yang terjadi pada Ustman bin Affan yang menyuruhnya Zaid bin Tasbit dan para sahabat lain untuk mengumpulkan al-Qur'an yang secara kebetulan juga, Khalifah pada saat itu Ustman bin Affan. Jika sekiranya Khuzaifah al-Yaman melakukannya sendiri, mungkin saja al-Qur'an itu sudah seperti bible yang ditulis bahkan dibaca dalam berbagai bahasa. 
Meskipun penulisan rasm Ustmani memunculkan beebagai kecaman khususnya sarjana barat yang mempertanyakan penggunaan dialeg Quraisy, bahkan mereka mempertanyakan tentang keabsahan mushaf yang dimiliki hafsah, yang masih membutuhkan seorang Zaid bin Tsabit dan para sahabat untuk menyalin kembali mushaf tersebut dengan menyatukan bacaan. Bahkan ini mengindikasikan bahwa mushaf yang dimiliki Hafsah sudah tidak layak lagi dijadikan acuan penulisan. ${ }^{5}$ Akan tetapi hal ini tidak berpengaruh karena penguasa pada saat itu adalah Ustman, jadi umat harus mengikuti khalifahnya.

Setelah al-Quran dikumpulkan maka timbullah persoalan yang baru yaitu mengenai penfasiran yang hal ini sangat rentan terhadap subjektifitas sipenafsir. Sepeninggalan Nabi dan sahabat menjadikan al-Quran sebagai rujukan utama bahkan menjadikan ayat sebagai penguat alibi dalam melakukan tindakan manusia. Hal ini berujung kepada interpretasi yang bermacam-macam dalam satu ayat.

Persoalan ini menjadi begitu delematis dikarenakan penafsiran klasik mulai dari Tafsīr al-Thabarī hingga ad-Dūr alMantsūr fī Tafīr bi Mantsūr fī Tafsīr bi al-Ma'tsūr karya as-Suyūthi. Menemukan problem yang sama yaitu penggunaan isrā’ iliyat yang secara tidak sengaja atau sengaja dikutip oleh para penafsir, hal ini ditambah lagi dengan pandangan mereka terhadap suatu mazhab

\footnotetext{
${ }^{5}$ Montgomery Watt, Richard Bell : Pengantar Al-Qur'an (Jakarta :
} INIS, 1998), h. 38-39. 
yang mereka anut sebagai contoh Tafsīr al-Kasyāf karya Zamakhsyāri yang sangat subjektif, bahkan penafsiran nya mendukung pendapat Mu'tazilah bahkan mengatas namakan mu'tazilah. ${ }^{6}$

Contoh lain menganai tafsir yang dipengaruhi oleh situasi politik ialah Tafsir karya al-Alusi, pada tahun 1267 tafsir tersebut diajukan kepada Raja yang berkuasa pada saat itu yaitu Raja Abdul Majid Khon. Ketika Raja tadi melihat hasil karya al-Alusi, beliau terkagum-kagum melihat hasil karyanya, dan merestuinya untuk diterbitkan. ${ }^{7}$ Bahkan seorang Hasan Hanafi berani melakukan perlawanan dengan Barat dengan mengusungkan slogannya dengan Islam Kiri, pemikirannya terus berkembang dan melahirkan ide-ide yang baru, semuanya itu berasal dari al-Qur'an sehingga Islam masuk dalam dunia politik dan bisa diakui di mata dunia. ${ }^{8}$

Hal ini yang menjadi latar belakang penulis untuk menulis asimilisasi antara politik dan tafsir. Bahkan al-Qur'an-pun yang tidak menggunakan rasio pada satu ayat pun masih saja melibatkan politik pada saat pengumpulannya. Apalagi sebuah tafsir yang sangat rentan terhadap pengaruh lingkungan dan pribadi panafsir.

PENAFSIRAN PADA MASA RASULULLAH HINGGA BANI UMAYAH

${ }^{6}$ Gamal al-Banna, terjemahan,. Evolusi Tafsir (Jakarta : Qisthi Press, 2004), h. 34-32.

${ }^{7}$ Mani’ Abdul Halim Mahmud, terjemahan.,Metodologi Tafsir Kajian Komprehensif Metode Para Ahli Tafsir, (Jakarta : PT Raja Grafindo, 2006), h. 205.

${ }^{8}$ Achmad Gholib, Teologi Dalam Perspektif Islam (Jakarta : UIN Jakarta Press, 2005), h. 149-143. 
Pembahasan ini berkaitan tentang gambaran mengenai beberapa hasil tafsir yang dibentuk pada masa klasik. Maksud penulis arti klasik disini ialah rentang waktu yaitu dari masa Nabi Muhammad saw hingga penfasiran pada akhir Bani Umayyah.

Pada masa Nabi Muhammad tafsir merupakan hal yang .paling menyenangakan karena penjelasan dalam satu ayat itu langsung di-cover oleh Nabi secara pribadi, berbeda hal nya ketika Nabi telah wafat.

Pada zaman Nabi Muhammad sahabat selalu bertanya kepada Rasulullah, akan tetapi penjelasan bukanlah mutlak dari Nabi pribadi, semua hal yang disampaikan oleh Nabi merupakan pedoman dari Allah swt, kadang-kadang beliau bertanya langsung kepada Jibril, akan tetapi Jibril tidak langsung memberikan penjelasan semua hal itu langsung diterima oleh Allah dan Jibril hanya sebagai media tafsir ayat-ayat yang ditanya oleh Nabi Muhammad saw. ${ }^{9}$

Hal ini mendeskripsikan bahwa sanya Nabi Muhammad saw tidak melakukan tafsir secara individu, akan tetapi bantuan dari Allah, bahkan hal ini bisa membantah kaum Orientalis yang mengatakan bahwa kita sebagai manusia biasa tidak mengetahui maksud Allah, dan hanya Allah yang tahun. Dalam firman Allah dijelaskan bahwasanya Nabi Muhammad berkata bukan berdasarkan hawa nafsunya dalam Surat al-Najm ayat 3-4 :

\footnotetext{
${ }^{9}$ Ahmad Syurbasi, terjemahan,.Studi Tentang Sejarah Perkembangan Tafsir al-Qur'an.(Jakarta : Kalam Mulia, 1999), h. 82-81
} 


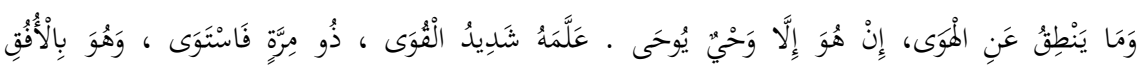

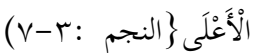

Artinya :Dan tidaklah yang diucapkannya itu menurut keinginannya, tidak lain adalah wahyu yang diwayhukan (kepadanya), yang diajarkan kepadanya oleh Jibril yang sangat kuat, yang mempunyai keteguhan maka menampakkan diri dengan serupa yang asli, sedang dia berada di ufuk yang tinggi. (al-Najm 3. 7).

Jikalau melihat kondisi Nabi Muhammad saw pada saat itu sudah sangat kuat, dikarenakan beliau sudah memiliki pengikut bahkan ketika Umar masuk Islam, penyebaran ayat-ayat al-Qur'an beserta tafsiran yang disampaikan sahabat sangat lah tergantung pada posisi Nabi saat itu.

Ketika Umar masuk islam kedudukan Quraisy semakin melemah, dan memperkuat kedudukan kaum muslimin. Bahkan Husein Haikal sendiri mengatakan bahwa ketika Umar masuk Islam maka muculah Muhammad sebagai pilitikus. Bahkan dakwahdakwah yang disampaikan oleh Nabi Muhammad tidak mendapat gangguan lagi oleh kaum Quraisy dan menjadikan ayat-ayat alQur'an bertebaran dimana-mana. ${ }^{10}$

Terlihat jelas faktor politik telah menjadikan Nabi Muhammad saw menjadi kuat dan hal ini sudah menjadi prediksi beliau. Karena ketika Umar masuk Islam, secara otomatis sebagian wailayah Makkah menjadi daerah kekuasaan Nabi. Walaupun penulis tidak terlibat langsung dalam peristiwa tersebut akan tetapi

${ }^{10}$ Muhammad Husein Haekal, terjemahan, Sejarah Hidup Muhammad (Jakarta : PT Mitra Kerjaya Indonesia,2006), h. 116-112. 
penulis berusaha berimajinasi bahwa sanya kekuasaan itu sangat penting pada saat itu hingga sekarang.

Setelah Nabi Muhammad telah memperkuat posisinya dalam bidang politik, maka isu yang terbaru yang disampaikan orang Quraisy ialah cerita Garāniq dan hal ini membuat perselisihan oleh mufasir hingga sekarang, bahkan kaum Orientalis sering mengungkit-ungkit peristiwa ini, sebagai kebodohan Nabi Muhammad saw. ${ }^{11}$

Walaupun Nabi Muhammad mengikut sertakan nama-nama tuhan orang Quraisy, menurut hemat penulis hal ini sangat wajar karena sahabat pada waktu terlalu menderita akibat gangguan orang Qurasiy. Sehingga beliau melakukan politiknya pada peristiwa garanik itu

Bahkan salah satu sarana yang digunakan metode nabi adalah politik, ketika itu Nabi Muhammad menjadi kepala Negara dan menjadikan al-Qur'an sebagai pedoman hidup, dengan bimbingan Nabi Muhammad melalui al-Qur'an yang dibawanya. Pada masa Muhammad lahir beberapa tokoh umat seperti Umar bin Khatab, yang mampu menciptakan tatanan hukum yang baik dalam satu negara. Selain itu juag Ali bin Thalib menjadi ahli tafsir dan Abdullah bin Abbas ahli pula dalam bidang tafsir. ${ }^{12}$ Semua hasil yang

${ }^{11}$ Haikal, Sejarah Hidup Muhammad, h. 121-117.

${ }^{12}$ Musyirifah Sunanto, Sejarah Islam Klasik Perkembangan Ilmu Pengetahuan Islam (Jakarta : Prenada Media, 2004), 22-17. 
diberikan Muhammad menciptakan mufasir-mufasir yang berkualitas adalah berkat kekuasaan yang sudah dipegangnya.

Ketika Nabi Muhammad wafat maka tampuk pimpinan pindah ke tangan Abu Bakar al-Shiddīqi,setelah itu Umar bin Khatab, Ustman bin Affan dan Ali bin Thalib. Keempat khalifah ini menjadi tokoh sentral sehingga Islam bisa berkembang hingga sampai di berbagai negara.

Pada masa Abu Bakar al-Shiddīqi terjadi perang Yamamah yang mengakibatkan banyak para hufadz meninggal, kekhawatiran Umar menjadi kenyataan, karena Umar takut kehilangan al-Qur'an. Sejarah mencatat bahwa reaksi Abu Bakar yang awalnya enggan untuk mengumpulkan al-Qur'an berubah seratus persen.

Salah satu hasil pemikiran Abu Bakar yang brilliant yang menurut penulis bisa dijadikan tolak ukur penafsiran pada masa Abu Bakar yaitu ketika Abu Bakar membacakan surat ali Imran ayat 104 ketika Rasulullah wafat dan umat Islam tergoncang batinnya. ${ }^{13}$ Firman Allah tersebut sebagai berikut :

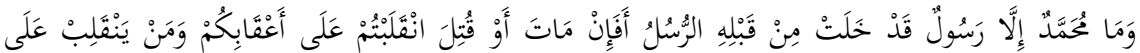

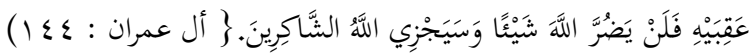

Artinya : Muhammad hanyalah seorang Rasul sebelumnya pun telah berlalu rasul-rasul. Apabila dia mati atau terbunuh kamu akan berbalik belakang? Barang siapa berbalik belakang sama sekali tidak akan merugikan Allah tetapi Allah akan memberi pahala kepada orang-orang yang bersyukur (Ali Imran : 144).

${ }^{13}$ Muhammad Husein Haikal, Terjemahan,. Abu Bakar As-Siddiq (Jakarta: Pustaka Liteara Antas Nusa, 2005), 29. 
Gambaran mengenai peristiwa ini, penulis meyakini inilah salah satu penafsiran yang dilakukan oleh Abu Bakar ketika Nabi Muhammad meninggal. Bahkan Abu Bakar tanpa bertanya kepada siapapun atau bahkan mengkompromikan pelafalan ayat tersebut kepada para sahabat waktu itu.

Mendengar hal tersebut Umar jatuh tersungkur ke tanah, bahkan umat Islam pada saat itu seperti kehilangan sosok yang paling sempurna. Bahkan seorang Umar pun tidak mampu menahan sedihnya, tetapi psikologi Abu Bakar begitu tenang, bahkan beliaulah yang mengumumkan kepada Umat Islam. ${ }^{14}$

Penulis tidak akan membahas terlalu panjang mengenai kematian Nabi Muhammad, akan tetapi penulis melihat terdapat salah unsur yang menjadikan Abu Bakar berani mengatakan seperti itu dihadapan Umat Islam yaitu kekuatan politik.

Hal ini bisa terlihat ketika Rasulullah masih hidup. Beliau menyuruh agar Abu Bakar al-Shiddīqi agar menjadi pimpinan rombongan jemaah haji dan memimpin 300 orang Muslimin. Ketika itu umat Islam telah menang dan telah menaklukkan semenanjung Arab dan berakhirnya ekspidisi ke Tabuk. Pada saat Abu Bakar memimpin Jemaah Haji, Nabi menyuruh Ali untuk menyusul Abu Bakar. Pada saat itu bertanya kepada Ali "Amir atau Ma'mur" jawab Ali : "Ma'Mur". ${ }^{15}$

\footnotetext{
${ }^{14}$ Haikal, Sejarah Hidup Muhammad, h. 30-29.
}

${ }^{15}$ Haikal, Sejarah Hidup Muhmmad, h. 537-536 
Peristiwa ini menggambarkan bahwa kedudukan Abu Bakar dimata umat Islam sangatlah urgen, dan mendeskrpisikan bahwa Abu Bakar adalah "tangan kanan” dari Rasulullah. Jadi sudah wajarlah ketika Nabi wafat maka Abu Bakar-lah yang pantas memberitahukan, bahkan menegur uamt jika ada yang mengaggap bahwa Muhammad yang diakui sebagai Nabi Umat Islam hanyalah manusia biasa.

Akan tetapi sejarah mencatat bahwa Umarlah yang paling berjasa dalam perkembangan Islam salah satunya ialah dengan merealisasikan perpaduan beberapa budaya negara seperti Syiria, Palestina, Mesir Kuno, Irak, dan sebagian wilayah Persi. Dalam bidang penafsiran hal yang dirubah oleh Umar yaitu permasalahan umat mengenai harta rampasan tepatnya pada surat al-Anfal. Berdasarkan beberapa riwayat bahwa harta rampasan itu harus dibagi kepada tentara yang berperang, dan itu merupakan perintah Nabi, akan tetapi Umar tidak melaksanakannya, justru harta tersebut dibagi kepada rakyat miskin untuk kepentingan negara. ${ }^{16}$ Terlihat jelas bahwa Umar dengan ketegasannya bisa merubah semua keadaan yang sangat monoton menjadi lebih dinamis.

Sedangkan pada masa Ustman bin Affan, sebaliknya, ketegasan yang dimiliki oleh Umar tidak nampak pada masa jabatan

${ }^{16}$ Sunanto, Sejarah Islam Klasik Perkembangan Ilmu Pengetahuan Islam h. 25 
Ustman bin Affan. Bahkan hal ini dimanfaatkan oleh keluarga Ustman bin Affan. Bahkan nepotisme semakin berkembang luas. ${ }^{17}$

Hanya sedikit sejarah mengenai Ustman khususnya dalam bidang tafsir, jasa beliau yang paling besar ialah menyatukan bacaan umat Islam dalam mushaf al-Qur'an. Sehingga dinamakan mushaf Ustmani.

Setelah masa Ustman, naiklah Ali bin Thalib sebagai khalifah, pada masa Ali banyak konflik yang terjadi diantaranya perebutan kekuasaan antara Ali, Thalhah dan Zubayr. Sebelum pengangkatan Ali peristiwa besar terjadi yaitu terjadi pemberontakan pada tahun 656. Pada saat itu pendukung Ali mengirim 500 orang pemberontakan ke Madinah, mereka mengepung rumah Ustman bin Affan dan membunuhnya, disaat itu pula anak Abu Bakar yang bernama Muhammad ikut bagian dalam pemberontakan tersebut, dan akhirnya Ustman bin Affan meninggal di tangan manusia. ${ }^{18}$

Ali adalah sosok yang paling dekat dengan al-Qur'an. Hal ini terlihat beberapa riwayat yang menggambarkan bahwa Ali adalah sosok yang paling akrab dengan al-Qur'an. ${ }^{19}$

Ketika Ali bin Abi Thalib menjadi kalifah terjadilah perang Jamal yaitu perang sesama orang Muslim antara Ali bin Thalib Islam, h. 32

${ }^{17}$ Sunanto, Sejarah Islam Klasik Perkembangan Ilmu Pengetahuan

${ }^{18}$ Philip K Hitty,terjemahan. History Of The Arabs (Jakarta: PT Serambi Ilmu Semesta, 2006), 221-220.

${ }^{19}$ Sayid Mujtaba Musawi Lari, terjemahan,. Imam Penerus Nabi Muhammad SAW(Jakarta : Lentera Basritama, 2004), h, 79-77. 
dengan Asiyah, Bani Umayah , dan Thalhah. Pada saat perang berlangsung terjadilah peristiwa tahkīm yang mengakibatkan beberapa aliran muncul di antaranya Kaum Khawarij (keluar dari kelompok Ali). ${ }^{20}$

Penafsiran yang dilakukan pada masa Ali bin Thalib yaitu ketika pada saat terjadinya perang Jamal dan peristiwa arbitrase (tahkim). ${ }^{21}$ Peristiwa yang dimaksud ialah tahkim yang dilakukan oleh Amr bin Ash yang mengangkat lembaran Mushaf sebagai solusi yang baik untuk menghentikan pertempuran dan hal ini disepakati oleh Ali bin Abi Thalib. Akan tetapi sebagian pendukung tidak menyepakati dan keluar dari kelompok Ali sehingga disebut Kaum Khawarij yang dipimpin oleh Abdullah ibn al-Kawa. ${ }^{22}$

Penerimaan Ali bin Thalib menurut penulis merupakan bentuk penafsiran yang dilakukan oleh Ali karena peristiwa tersebut melibatkan ayat -ayat al-Qur'an. Walaupun tidak secara ekplisit akan tetapi perilaku Ali sudah menggambarkan bahwa beliau paham dengan ayat tersebut tanpa perlu berunding lagi beliu telah melakukan penafsiran secara individu.

Paska runtuhnya kekuasaan Ali, banyak hal yang terjadi di dunia Islam di antaranya berdirinya Dinasti Umayyah, setelah itu

${ }^{20}$ Hasan Ibrahim Hasan, terjemahan,. Sejarah dan Kebudayaan Islam (Jakarta : Kalam Mulia), 509.

${ }^{21}$ Gholib, Teologi Dalam Perspektif Islam, h. 45.

${ }^{22}$ Yunahar Ilyas, "Sejarah Pemikiran Khawarij dari Politik ke Theologi” Paradigma PemikiranIslam http://hauzah.wordpress.com/2007/11/29/sejarah-pemikiran-khawarij-daripolitik-ke-teologi/" November 29, 2007 (diakses Juni, 2010) 
munculnya kaum Khawārij, Kaum Mu'tazilah, Kaum Jabariyah, Kaum Murji'ah, yang semuanya mempunyai tafsiran yang berbedabeda. Penulis tidak akan membahas satu persatu aliran tersebut akan tetapi penulis akan menampilkan beberapa contoh penafsiran yang sangat subjektifitas bahkan mendukung kelompoknya masingmasing.

a. Contoh penafsiran Mu'tazilah

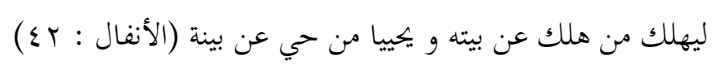

Artinya: .......... yaitu agar orang binasa itu binasanya dengan keterangan yang nyata dan agar orang yang hidup itu hidupnya dengan ketrangan yang nyata pula. (al-Anfal: 42)

Dalam pandangan mengenai ayat ini ialah kebaikan dan keburukan dapat dikenal dengan menjauhi yang buruk, adanya beban tanggung jawab (taklīf) merupakan cobaan dan ujian terhadap manusia yang diturunkan kepada para rasul. Sehingga bagi golongan Mu'tazīlah wajib hukumnya mensyukuri nikmat sebelum diturunkan wahyu. $^{23}$

b. Penafsiran Golongan Khawarij

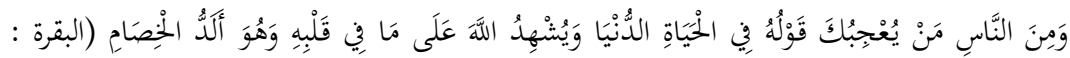

$$
\begin{aligned}
& \text { ( } Y \cdot \varepsilon
\end{aligned}
$$

Artinya : Dan diantara manusia ada orang yang ucapannya tentang kehidupan dunia menarik hatimu, dan dipersaksikannya kepada Allah (atas kebenaaran) isi hatinya padahal ia adalah penantang yang paling keras.(al-Baqarah: 204)

${ }^{23}$ Asy-Syahrastani, terjemahan., al-Milāl wa al-Nihāal(Surabaya : PT Bina Ilmu, 2008), 39. 
Menurut Kaum Khawārij ayat ini didedikasikan buat Ali bin Abi Thalib karena Ali bagi mereka telah kafir. Bahkan mereka membenarkan tindakan Abd al-Rahman ibn Maljam yang membunuh Ali bin Thalib. Bahkan mereka memberikan tafsiran terhadap ayat al-Qur'an berkenaan dengan Abdurahman yang merupakan seorang pejuang ayatnya sebagai berikut : ${ }^{24}$

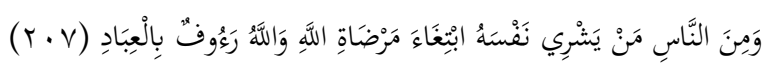

Artinya : dan diantara mansia ada orang yang mengorbankan dirinya karena mencari keridhaan Allah ....... (al-Baqarah 207)

Sungguh ironis disaat Islam telah berkembang luas justru penafsirannya yang menyimpang dan berlebihan penyampaiannya, bahkan penafsirannya terlalu subjektif dan hal itu terlalu nampak untuk ditutupi.

\section{c. Penafsiran Golongan Murji'ah}

Bagi mereka iman adalah pengenalan kepada Allah dengan menaati-Nya meninggalkan keinginan dan rencana pribadi serta menyerahkan segala-galanya kepada Allah dan mencintai Allah dengan sepenuh hati. Barang siapa yang pada dirinnya terhimpun semua hal yang disebutkan diatas maka dia dikatakan sebagai orang yang beriman. Perbuatan selain diatas bukan termasuk iman, hal ini bisa dilihat ungkapan mereka dengan mengambil surat al-Baqarah sebagai penguat argument mereka. Ayatnya sebagai berikut :

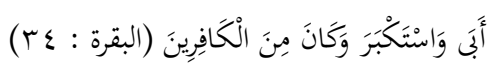

Artinya : ia enggan dan takabur dan adalah dia termasuk golongan orang-orang yang kafir (al-Baqarah : 34).

${ }^{24}$ Asy-Syahrastani, al-Milal wa al-Nihal, h.107-106. 


\section{d. Penafsiran Golongan Syiah}

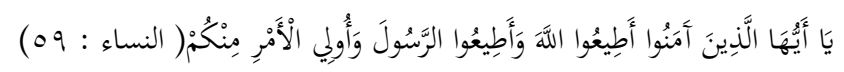

Artinya : Wahai orang-orang beriman taatlah kamu kepada Allah dan Rasul dan Ulim Amri diantara kamu.

Menurut golongan Syiah ayat ini membicarakan tentang Ali bin Thalib, karena Ulil Amri bagi mereka adalah Ali. ${ }^{25}$ Terlihat jelas bahwa sanya golongan Syiah terlalu sujektif dalam menafsirkan ayat ini, bahkan jika digunakan ayat pada masa sekarang tidak akan berfungsi lagi. Padahal Ulil Amri ini merupakan kepala pemerintahan yang berada di setiap negara.

Setelah mengemukakan emapat golongan dan tafsirnya masing-masing terlihat jelas semua golongan yang disebutkan penulis, sangatlah mementingkan golongan mereka dengan mengatas namakan al-Quran, dan alat yang mereka gunakan adalah tafsir.

Walaupun terdapat beberapa golongan yang menentang Bani Umayyah, Islam tetap berjaya. Hal ini bisa terlihat dari pencapaian Bani Umayah dalam penyebaran Islam dan luasnya pengembangan ilmu pengetahuan dan mencetak orang-orang beriilmu seperti Ibn Ajbar (seorang dokter khalifah dan berpengaruh terhadap keputusan pejabat setempat), Sibawaihi (Ilmu Nahwu), Al-Zuhri (tokoh hadits), dan masih banyak yang belum sempat disebutkan. ${ }^{26}$ B. Pasca Bani Umayah

\footnotetext{
${ }^{25}$ Asy-Syahrastani, al-Milal wa al-Nihal, h. 106-107.

${ }^{26}$ Sunanto, Sejarah Islam Klasik Perkembangan Ilmu Pengetahuan
} Islam, h. 44 
Pada masa ini banyak penafsir bermunculan di antaranya Ibn Katsir, al-Rāzi, Ibn jarir al-Ṭabāri, al-Zamakhsyāri, Ibn al-Ṭiyah, alSyaukāni. Mereka semua ini adalah para penafasir yang mempunyai kelebihan masing-masing . Misalnya al-Zamakhsyāri kental dengan bahasanya, Fakhrudin al-Razi mempunyai kelebihan dalam bidang filsafatnya.

Alasannya sangat jelas, mengapa banyak para penafsir yang muncul pada masa ini , dikarenakan pada masa Bani Abbasiyah dalil naqli dan aqli berkembang luas bahkan pemerintah setempat mengizinkan hal tersebut. Sehingga ilmu tafsir pada masa ini sangat berkembang pesat bahkan diakui bahwa untuk menambah cerita dalam tafsir tersebut digunakanlah isrā'iliyāt dan ini bisa terlihat dalam Tafsir Ibn Kātsir tiga puluh jilid. ${ }^{27}$

Pada masa ini berkembangan beberapa aliran seperti Mu'tazilah yang diwakili oleh Zamakhsyāri dan Abu Bakar Asma. Sedangkan ahlu Sunnah di wakili oleh Ibn Katsīr.

Penafsiran pada masa ini lebih sistematis dikarenakan setiap mufasir sudah menggunakan metodenya masing-masing dan mendukung pendapat mazhabnya masing-masing seperti Ibn Katsir mendukung terhadap pandangan Imam Syafi' i. ${ }^{28}$

Adapun metode yang digunakan Ibn Katsir ialah pertama menafsirkan al-Qur'an dengan al-Qur'an, kedua meneliti sunnah

Islam h. 59

${ }^{27}$ Sunanto, Sejarah Islam Klasik Perkembangan Ilmu Pengetahuan

${ }^{28}$ (Mahmud, 2006, 61) 
yang terdapat penjelasan al-Qur'annya, ketiga mencari pendapat sahabat dalam menjelaskan suatu ayat, keempat menjadikan tabi'in referensi terakhir dalam menjelaskan ayat. ${ }^{29}$

Hal berbeda terhadap apa yang dilakukan Fakhruddi al-Rāzi yang pemmikiran lebih cenderung kepada filsafat bahkan tafsirnya dikategorikan sebagai tafsir bil ra'yi karena penggunaan akan dalam metode penafsirannnya. ${ }^{30}$ Bahkan tafsirnya yang bernama Mafātihul al-Ghaib menjadi rujukan para raja-raja disekitar daerah tersebut seperti Syihabuddin al-Ghauri, Sultan Ghaznah, dan Sultan 'Ala alDīn Khawārizmi Syāh. ${ }^{31}$

Jikalau dukungan raja tidak ada, mustahil nama al-Rāzi bisa masyhur hingga sekarang, sekali lagi penulis mengatakan bahwa gambaran mengenai kisah al-Rāzi ini, menunjukkan bahwa kekuatan politik sangat berpengaruh terhadap perkembangan ilmu tafsir.

Tokoh ketiga yang selanjutnya ialah Zamakhsyāri beliau secara jelas mengakui penganut paham mu'tazilah. Bahkan kitab alKasyāf dibuat untuk mendukung pemahaman dan mazhabnya.

Segi kebahasaan zamakhsyāri sudah tidak perlu diragukan lagi karena, beliau berhasil mengungkapkan keindahan al-Qur'an dari gaya bahasanya dan balaghahnya.Bahkan para penganut

\footnotetext{
${ }^{29}$ Mahmud,Metodologi Tafsir Kajian Komprehensif Metode Para Ahli Tafsir, h. 62

${ }^{30}$ Al-Dzahābi, al-Tafsiæ wa al-Mufassiruł Jilid 1, h. 207

${ }^{31}$ Mahmud,Metodologi Tafsir Kajian Komprehensif Metode Para Ahli
} Tafsir,h. 322. 
mu'tazilah pada masa itu sangat mendukung tentang adanya tafsir ini. Walaupun dalam mukadimah Ibn Khaldun beliau dikategorikan bukan paham Mu'tazilah, karena beliau hanya membela paham tersebut bukan pengikut. ${ }^{32}$

Walaupun Zamakhsyāri tidak terlibat secara langsung dalam politik akan tetapi beliau telah membela kaum tertentu sehingga, begitu banyak pendukung yang datang kepada tafsirnya.

\section{PENAFSIRAN PADA ABAD MODERN}

Abad modern lebih komplek dibanding masa klasik, karena penafsiran pada saat itu dibutuhkan oleh masyarakat, bahkan ditunggu dan dijadikan fatwa dalam sebuah negara. Adapun tokoh pada masa ini ialah Muhammad Abduh, Rasyid Ridho, Sayyid Qutb, Aisyah Abdurahman Binti Syāti' dan Tanțawi Jauhari.

Sebagai conoth penulis menyebutkan dalam Tafsir al-Manār karya Muhammad Abduh dan Rasyid Ridho. Pada saat itu masyarakat mempercayai dengan adanya jin dan sihir, akan tetapi menurut Rasyid Ridho hal tersebut mustahil. Akibat dari penggunaan akal secara berlebihan maka beliau menyatakan dalam firman Allah surat al-A'rāf : 27 :

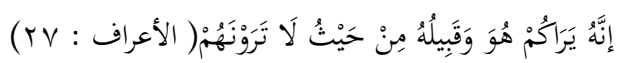

Artinya : Sesungguhnya ia (jin) dan pengikut-pengikutnya melihat kamju dari satu tempat yang kamu tidak dapat melihatnya mereka. (Surat al-A'raf : 27)

${ }^{32}$ al-Qatțān,Mabakith fi 'Ulum al-Qur'an, h. 509 
Rashid Ridho menolak pendapat-pendapat ulama yang mengatakan bahwa Syaitan bisa dilihat, dan beliau mengemukakan firman Allah Surat al-A'raf. Menurut Rasyid Ridho orang yang melihat jin atau Syaitan hanyalah akibat hayalan semata atau dia melihat suatu binatang yang aneh sehingga diduga itu jin. ${ }^{33}$

Perlu diingat bahwa Tafsir al-Manār adalah tafsir berawal dari majalah dan ceramah-ceramah Muhammad Abduh yang dikumpulkan oleh Muridnya bernama Rasyid Ridho. Bahkan Tafsir al-Manarnya ini bisa terkenal karena latar belakang politik yang baik, sehingga beliau sempat tinggal di Perancis. Sedangkan tokoh-tokoh yang berada dibelakang Abduh adalah orang-orang ternama seperti Jamaludin al-Afgan, Syaikh Dawisyi, Muhammad al-Basyuni, tokohtokoh yang sebutkan penulis tadi adalah tokoh-tokoh yang berpengaruh di Mesir. ${ }^{34}$

Gambaran mengenai Abduh tadi, mengindikasikan bahwa situasi politik telah dipegang oleh Abduh bahkan, pada saat itu Abduh telah sampai ke Perancis sehingga membuka pemikirannya untuk menghilangkan taqlid di Mesir bahkan memurnikan ajaran Islam secara utuh.

Tokoh lain pada abad ini ialah Sayyid Qutb, tafsir beliau yang berjudul F̄̄ Zilālil Qư'ān, merupakan representasi terhadap pemikiran Hasan al-Banna. Pada masa itu terdapat gerakan politik

\footnotetext{
${ }^{33}$ Quraish Shihab, Rasionalitas al-Qur'an Studi Kritis atas Tafsir alManar (Jakarta : Lentera Hati, 2006), 97.

${ }^{34}$ Shihab, Rasionalitas al-Qur'an Studi Kritis atas Tafsir al-Manar, h. $12-14$
} 
Islam yang mampu membangkitkan kesadaran di seluruh dunia Islam. ${ }^{35}$

Bahkan tafsir ini memberikan pola dan pedoman hidup manusia pada saat itu beliau mengangkat topik-topik yang menggerakan jiwa masyarakat pada saat itu , berikut ini tafsir yang sering digunakan dalam menggerakan masa. Firman Allah dalam surat al-Ahzab ayat 36 dan Al-Jaziyah 18-19.

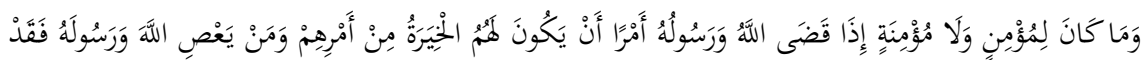

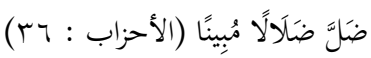

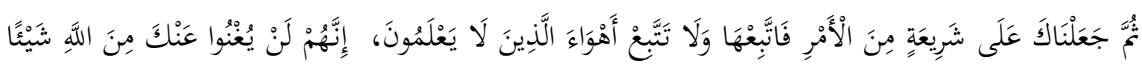

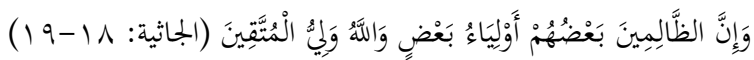
Artinya : Dan tidaklah patut bagi laki-laki mu'min dan tidak (pula) bagi perempuan mukmin apabila Allah dan Rasul-Nya telah menetapkan sesuatu ketetapan, akan ada bagi mereka pilihan (yang lain) tentang urusan mereka (al-Ahzab: 36)

Kemudian kami jadikan kamu berada di atas suatu (syariat) peraturan dari urusan (agama) itu maka ikutilah syariat itu dan janganlah kamu mengikuti hawa nafsu orang-orang yang tidak mengetahui, Sesungguhnya mereka sekali-kali tidak akan dapat menolak daripadamu sedikit pun dari siksaan Allah. Dan sesungguhnya orang yang zalim itu sebagainya menjadi penolong bagi sebagian yang lain dan Allah adalah pelindung orang-orang yang bertakwa. (al-Jathiyah 18-19)

Inilah ayat yang dijadikan oleh Sayid Qutb menempuh metode tertentu bagi penulisan tafsirnya. Setelah itu beliau menggunakan athar-athar yang sohih kemudian berusaha

35al-Qațtān, Mabahith fi 'Ulum al-Qur'an. h. 512. 
membagkitkan kesadaran dan membetulkan pemahaman dan mengaitkan Islam dalam tatanan kehidupan umat Islam. ${ }^{36}$

Secara singkat bahwasanya penafsiran mempunyai tujuan tertentu pada masa modern ini. Secara tidak langsung penafsir mempunyai keinginan agar mengubah paradigma berpikir melalu tafsir. Akan tetapi hal ini membutuhkan kekuatan yang sifatnya politik.

Adapula tokoh yang menggunakan penafsiran sebagai alat perjuangannya yaitu Hasan Hanafi. Alasan penulis memasukkan beliau karena pemikirannya sama dengan Hasan al-Banna.

Akibat banyak membaca karya Sayyed Qutb dan menggunakan pemikiran Hassan al-Banna dengan mengusung Islam kiri, bahkan beliau memberikan solusi kepada masyarakat, metode itu adalah fenomenologi. Alasan beliau sangat jelas karena dunia Islam menghadapi tiga bahaya besar dibanding imprealisme, zionisme, dan kapitalisme. Akan tetapi dunia Islam akan menghadapi kemiskinan, penindasan, dan keterbekalangan. ${ }^{37}$

Akan tetapi nasib Hasan Hanafi gagal total karena pada saat itu Mesir memeliki pemimpin yang diktator dan hal ini menjadikan Hasan Hanafi tidak leluasa bergerak dan sering mendapat kecaman dari penguasa. ${ }^{38}$

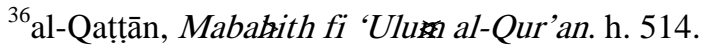

${ }^{37}$ Gholib, Teologi Dalam Perspektif Islam, h., 149.
} 
Inilah salah satu contoh bahwa jika penafsiran seorang mufasir atau ide-ide dari penafsir tidak sejalan dengan penguasa politik mengakibatkan kegagalan, bahkan menjadikan masyarakat kurang tanggap terhadap hal seperti ini. Padahal pemikiran Hasan Hanafi telah dirasakan umat Islam sekarang.

\section{KESIMPULAN}

Setelah memaparkan beberapa persoalan yang terjadi dari masa Nabi Muhammad hingga penafsiran modern. Penulis berkesimpulan bahwa segala macam paradigma yang akan dituangkan dalam tafsir membutuhkan latar belakang politik yang mampu menarik masyarakat.

Mulai dari Nabi ketika menjadi pimpinan dalam sebuah negara, hingga Sayyid Qutb yang menggunakan gerakan Islam. Ada satu hal yang paling urgen dalam masalah penafsiran yaitu latar belakang guru, jikalau guru-gurunya sangat berpengaruh maka hal ini bisa jadi suatu kekuatan disamping politik.

Karena jika guru itu berpengaruh maka apa yang dihasilkan oleh si penafsir maka itu akan cepat diterima oleh masyarakat sebagai contoh Muhammad Abduh.

Ada juga sisi yang menarik dalam makalah ini yaitu ketika penafsiran yang dilakukan oleh beberapa golongan seperti Syiah, Khawarij. Sangat terlihat jelas bahwa tafsir al-Qur'an hanya dijadikan sebagai benteng untuk menangkis segala macam pemikiran yang 
Volume 01, Number 1, June 2019: 49-75

masuk. Sehingga penafsirannya terlihat aneh-aneh bahkan diluar logika manusia.

\section{DAFTAR PUSTAKA}

Al-Banna, Gamal. terjemahan,. Evolusi Tafsir. Jakarta : Qisthi Press, 2004.

Basya, Hilaly. "Mendialogkan Teks Agama dengan Makna Zaman : Menuju transformasi Sosial”. Al-Huda Vol III (2005) : 37-9.

Ghalib, Ahmad. Teologi Dalam Perspektif Islam. Jakarta : UIN Jakarta Press, 2005.

Haekal, Muhammad Husein. terjemahan. Abu Bakar As-Siddiq. Jakarta : Litera Antar Nusa, 2005.

Hasan, Hasan Ibrahim. terjemahan,. Sejarah dan Kebudayaan Islam 1. Jakarta : Kalam Mulia, 2002.

Hitti, Philip K. terjemahan,. History Of the Arabs. Jakarta : PT Serambi Ilmu Semesta, 2006.

Ilyas, Yunahar Word press, The. http://id.wordpress.com/tag/khawarij/ (di akses Juni 2010)

Al-Qaț̣ān, Mannā' Khalīl. terjemahan. Studi Ilmu-Ilmu al-Qur'an. Bogor : Litera Antar Nusa, 2004.

Shihab, Quraish. Rasionallitas al-Qur'an Studi Kritis atas Tafsir alManar. Jakarta : Lentera Hati, 2006.

Sunanto, Musyrifah. Sejarah Islam Klasik Perkembangan Ilmu Pengetahun. Jakarta : Prenada Media, 2004.

Syrubasi, Ahmad. terjemahan,. Sejarah Perkembangan Tafsir al-Qur'an. Jakarta : Kalam Mulia, 1999. 
Darlis. : Urgensi Kekuatan Politik Dalam Penafsiran Al-Qur’an

Al-Dzahābi, Muhammad Husein. al-Tafsīr wa al-Mufassirūn. Beirut : Makatabah Mus'āb bin 'Umar, 2004.

Ma'rifat, Hadi. terjemahan,. Sejarah al-Qur'an . Jakarta : al-Huda : 2007. 